\title{
ROLE OF RADIATION AS EFFECTIVE INTERVENTION IN A $\beta$ INDUCED OXIDATIVE STRESS IN ANIMAL MODEL OF ALZHEIMER'S DISEASE
}

\author{
KHAN ${ }^{1 *}$, KAMAL R ${ }^{1}$, DHAWAN DK ${ }^{2}$, VIJAYTA DANI CHADHA ${ }^{1}$ \\ ${ }^{1}$ Centre for Nuclear Medicine, Panjab University, Chandigarh, Punjab, India. ${ }^{2}$ Department of Biophysics, Panjab University, Chandigarh, \\ Punjab, India. Email: vdchadha@pu.ac.in
}

Received: 19 July 2018, Revised and Accepted: 19 September 2018

\section{ABSTRACT}

Objective: The present study was undertaken to study the therapeutic effects of low dose fractionated cranial X-irradiation on reducing the amyloidbeta $(A \beta)$ induced oxidative stress burden in an animal model of Alzheimer's disease (AD).

Methods: S.D. female rats received an intracerebroventricular injection of A $\beta$ peptide at stereotaxically defined points. Experimental sessions were conducted by randomly dividing animals into four groups, namely sham-operated, $A \beta$-injected, and $A \beta$ injection followed by cranial X-irradiation and only cranial X-irradiated. Anesthetized animals received $5 \mu \mathrm{l}$ synthetic A $\beta$ peptide injection with a $10 \mu \mathrm{l}$ Hamilton microsyringe with the needle kept in place for a period of $2 \mathrm{~min}$ following injection. Sham-operated group received $5 \mu$ l of bidistilled water instead of $A \beta$ peptide. Animals were treated 6 weeks post-surgery with fractionated radiation of 2 Gy for 5 days. Neurobehavior studies were undertaken to confirm memory impairment along with biochemical indices involved in the antioxidant defense system.

Results: Fractionated cranial X-irradiation proved effective in restoration of activity of enzymes involved in the antioxidant defense system; the lipid peroxidation and catalase levels that showed a significant increase in A $\beta$-treated group decreased on subsequent X-irradiation. Moreover, the decrease in the superoxide dismutase, glutathione, glutathione-S-transferase, and glutathione reductase levels witnessed an increase post-irradiation, implicating the X-irradiation to be an effective intervention to restore the redox status of the oxidatively stressed brain cells in $\mathrm{AD}$ condition.

Conclusion: The present study evaluated the therapeutic potential of low dose fractionated cranial X- irradiation by mitigating the amyloid-induced oxidative stress suggesting a novel treatment for AD-associated pathologies.

Keywords: Fractionated X-irradiation, Oxidative stress, Neurodegeneration.

(C) 2019 The Authors. Published by Innovare Academic Sciences Pvt Ltd. This is an open access article under the CC BY license (http://creativecommons. org/licenses/by/4. 0/) DOI: http://dx.doi.org/10.22159/ajpcr.2019.v12i1.28550

\section{INTRODUCTION}

Alzheimer's disease (AD) is an accelerating public health problem worldwide. As the percentage of the population over the age of 65 years increases, the prevalence of the disease is anticipated to increase proportionately, making the treatment of AD a major health priority [1]. Clinical manifestations include progressive impairments in visuospatial perceptions, memory, calculations, and behavior inevitably affecting all intellectual functions leading to a complete dependence for basic functions of daily life, and premature death [2].

In 1906, a German physician pioneered to describe the pathologic abnormalities in the autopsied brain of a woman who was affected for years by memory impairment and progressive loss of cognitive function [3]. He reported the presence of a collection of dense deposits or plaques outside the neurons and bands of fibers or tangles within the brain cells [4]. These extracellular senile plaques and intracellular neurofibrillary tangles of tau have been recognized to be the two core pathological hallmarks that define the AD.

The senile plaques as described by Alzheimer were isolated by Glenner and Wong in 1984 are composed of amyloid-beta (A $\beta$ ), a proteolytic fragment of amyloid precursor protein (APP). APP is an integral membrane glycoprotein expressed in all tissues and undergoes cleavage to release the secretory form (SAPP) and subsequent cleavage by $\Upsilon$-secretase to release $38-42$ amino acids long $A \beta$ peptide $[5,6]$. However, two variants, $A \beta 1-40$ and $A \beta 1-42$, which differ at the carboxyl terminus are the predominant plaque proteins found in the blood and cerebrospinal fluid at nanomolar levels [7]. The other hallmark feature of AD brains - neurofibrillary tangles are composed primarily of Tau, a microtubule-associated protein which has extensively been investigated as a biomarker. In $\mathrm{AD}, \mathrm{A} \beta$ fibril induces tau hyperphosphorylation at many sites and enzyme-linked immunosorbent assays have been developed to recognize various phosphorylated epitopes such as threonine 181 and 231 and serine 199, 235, 396, and 404 [8]. As a result of this aberrant phosphorylation, tau is unable to bind and stabilize microtubules, possibly leading to axon degeneration and fibrillary accumulation in the cytoplasm, neutrophil threads, and dystrophic neuritis [9]. The AD pathologies (plaques and tangles) are found predominantly in the frontal and temporal lobes, including the hippocampus. In more advanced cases, the pathology extends to other areas of the cortex, including the parietal and occipital regions leading to cell death and global reduction in cholinergic activity and other important neurotransmitters too $[10,11]$.

Low dose fractionated radiation therapy plays an important role in the complex management of primary and secondary brain tumors and has been used therapeutically in both malignant and benign conditions in multiple organ sites, including symptomatic amyloidosis. However, the neuroprotective potential of low dose fractionated therapy is still underexplored. Since the pathophysiology of the disease is largely linked to the build of the $A \beta$ in the brain, radiation therapy has demonstrated a $50-80 \%$ reduction in $A \beta$ plaques in both the hippocampus and cortex of transgenic murine models in an exclusive study conducted by Wilson and Marples 2016 [12].

Knowing that the conventional pharmacologic interventions target symptoms but fall short of addressing underlying contributing factors for $\mathrm{AD}$, the need to investigate an entirely novel strategy to treat $\mathrm{AD}$ pathologies is absolutely crucial. Hence, to alleviate the sufferings of 
this neurodegenerative disorder of such a high global prevalence, this innovative study seeks to investigate the low dose fractionated cranial $\mathrm{X}$-irradiation induced therapeutic effects on $\mathrm{A} \beta$ based models of AD.

\section{METHODS}

\section{Animals}

Healthy female Sprague Dawley (S.D.) rats weighing 180-220 g were procured from the Central Animal House of the Panjab University, Chandigarh. Animals were acclimatized to laboratory conditions before experimentation and were housed in polypropylene cages under a hygienic bed of husk in a well-ventilated departmental animal house. The animals were maintained on a standard laboratory pelleted feed (Ashirwaad Industries, Tirpari, and Punjab) and water ad libitum throughout the period of experimentation. All the procedures on rats were done in accordance with ethical guidelines for care and use of laboratory animals, which were approved, by Institutional Animal Ethics Committee, Panjab University Chandigarh, India.

Experimental sessions were conducted by randomly dividing animals into four groups Group 1: Sham-operated, Group 2: $\mathrm{A} \beta$ injected, Group 3: $A \beta$ injection followed by cranial X-irradiation, and Group 4: Only cranial X-irradiated (radiation control).

\section{Chemicals}

$\mathrm{A} \beta$ (1-40) was purchased from Sigma (St. Louis. MO). Other chemicals were purchased from Sigma (St. Louis, USA), Merck, Sisco Research Laboratories Pvt., Ltd., (Mumbai, India) and HiMedia Chemicals. The Allengers Medical Systems Ltd., USA, provided the X-ray machine for the experiments to be conducted.

\section{Surgical procedure}

The rats were anesthetized intraperitoneally with sodium thiopentone ( $45 \mathrm{mg} / \mathrm{kg}$ i.p.) and placed in a stereotaxic instrument. The scalp was incised and drilled at stereotaxically defined lateral cerebral ventricle points (1.2 $\mathrm{mm}$ behind the bregma, $2 \mathrm{~mm}$ meta, and $4 \mathrm{~mm}$ deep) [13]. Anesthetized animals of Group 2 and Group 3 received $5 \mu$ synthetic A $\beta$ (1-40) peptide injection with a $10 \mu \mathrm{l}$ Hamilton microsyringe with the needle kept in place for a period of 2 min following injection.

Animals of the Group 3 were subjected to 10Gy X-irradiation (fractionated dose, 2 Gy $\times 5$ days) 4-5 weeks post-intracerebroventricular administration of the peptide. The radiation control group (Group 4) was also be subjected to a similar dose of X-irradiation, and the sham-operated rats (Group 1) received only the vehicle solution (bidistilled water).

\section{Biochemical assays}

Animals were sacrificed by decapitation after anesthetization with diethyl ether. The brains were immediately removed and rinsed with ice cold isotonic saline. Tissue homogenates $(20 \% \mathrm{w} / \mathrm{v})$ were prepared in ice-cold $10 \mathrm{mM}$ PBS (pH 7.4). Homogenates were centrifuged at $1000 \mathrm{~g}$ for $10 \mathrm{~min}$ at $4^{\circ} \mathrm{C}$. Pellets were discarded, and the supernatants were used to determine the reduced glutathione (GSH) and lipid peroxidation (LPO) levels. The supernatants were further re-centrifuged at 10,000 g for $30 \mathrm{~min}$ at $4^{\circ} \mathrm{C}$ to obtain post-mitochondrial fraction used for the rest of the biochemical estimations.

\section{LPO}

The quantitative measurement of LPO was done according to the method of Wills [14]. Brain homogenates were mixed with ice cold $10 \%$ trichloroacetic acid (TCA) and were centrifuged at $800 \mathrm{~g}$ for $10 \mathrm{~min}$. To the supernatant, $0.67 \%$ thiobarbituric acid (TBA) was added, and the pink color developed by boiling at $100^{\circ} \mathrm{C}$ was read at $532 \mathrm{~nm}$ using UV visible spectrophotometer. Since malondialdehyde (MDA) is a degradation product of peroxidized lipids, the development of pink color with the absorption characteristics (maximum at $532 \mathrm{~nm}$ ) as TBAMDA chromophore has been taken as an index of LPO. The results were expressed as nanomoles of MDA per milligram of protein. The amount of MDA formed was calculated on the basis of the molar extinction coefficient of MDA-TBA chromophore $\left(1.56 \times 10^{5} / \mathrm{M} / \mathrm{cm}\right)$.

\section{Superoxide dismutase (SOD)}

The assay was performed according to the method of Kono, 1978 [15]. The assay of SOD is based on the inhibition of the formation of NADHphenazine methosulfate - nitroblue tetrazolium (NBT) formazan. The reduction of NBT to blue formazon mediated by hydroxylamine hydrochloride was determined under aerobic conditions. Addition of SOD inhibits the reduction of NBT by superoxide anions generated by photo-oxidation of hydroxylamine hydrochloride, and the extent of inhibition was taken as a measure of enzyme activity. The reaction mixture contained $1.3 \mathrm{~mL}$ of $50 \mathrm{mM}$ sodium carbonate solution in $0.1 \mathrm{mM}$ ethylenediaminetetraacetic acid, $0.5 \mathrm{~mL}$ of $96 \mu \mathrm{M} \mathrm{NBT}$, and $0.1 \mathrm{~mL}$ of $0.6 \%$ Triton $\mathrm{X}-100$. The reaction was initiated by the addition of $0.1 \mathrm{~mL}$ of $20 \mathrm{mM}$ hydroxylamine hydrochloride ( $\mathrm{pH} \mathrm{5.0)}$ ), and an appropriate amount of tissue homogenate and the rate of NBT reduction was measured by a spectrophotometer. The activity of the enzyme was expressed as international unit/mg protein, where one unit of enzyme is the amount of enzyme-inhibiting the rate of reaction by $50 \%$.

\section{Catalase}

Catalase was spectrophotometrically determined using the method described by Catalase [16]. Briefly, $3 \mathrm{ml}$ reaction mixture in a sample cuvette contained $50 \mathrm{mM}$ potassium phosphate buffer $(\mathrm{pH} 7.0), \mathrm{H}_{2} \mathrm{O}_{2}$ at a concentration where it shows an optical absorbance of 0.5 , and the brain homogenate. Every sample was analyzed simultaneously with appropriate blanks without $\mathrm{H}_{2} \mathrm{O}_{2}$. The decrease in absorbance on the decomposition of $\mathrm{H}_{2} \mathrm{O}_{2}$ was measured at $240 \mathrm{~nm}$ on a double beam spectrophotometer.

The amount of $\mathrm{H}_{2} \mathrm{O}_{2}$ decomposed was calculated on the basis of the molar extinction coefficient of $\mathrm{H}_{2} \mathrm{O}_{2}(0.0394 / \mathrm{M} / \mathrm{cm})$, and the results were expressed as $\mu$ moles of $\mathrm{H}_{2} \mathrm{O}_{2}$ decomposed $/ \mathrm{min} / \mathrm{mg}$ protein.

\section{Glutathione reductase (GR)}

GR is a flavoprotein that catalyzes the NADPH-dependent reduction of glutathione disulfide (GSSG) to reduced GSH. The utilization of NADPH is directly related to the activity of GR. The assay was performed by the method of Carlberg and Mannervik (1985) wherein phosphate buffer (0.2 M), NADPH and GSSG were added to the cuvette directly [17]. The reaction was initiated by the addition of sample, and the decrease in absorbance was followed for $2 \mathrm{~min}$ at $340 \mathrm{~nm}$. A unit of GR activity is defined as the amount of enzyme that catalyzes the oxidation of $1 \mu \mathrm{M}$ $\mathrm{NADPH} / \mathrm{min} / \mathrm{mg}$ protein.

$6.22 \times 10^{-3} / \mathrm{mM} / \mathrm{cm}$ is taken as the molar absorption coefficient of NADPH.

\section{Total glutathione (TG)}

The TG content was measured following the method of Zahler and Cleland [18]. The method is based on the principle of reduction with dithioerythritol and determination of the resulting monothiols with 5,5'-dithiobis-(2-nitrobenzoic acid) (DTNB) in the presence of arsenite. The disulfide in the sample was mixed with dithioerythritol, and the reduction is allowed to proceed for $20 \mathrm{~min}$. After reduction, tris buffer and sodium arsenite were mixed followed by the addition of DTNB (prepared in sodium acetate) and the absorbance is recorded for $3 \mathrm{~min}$. The TG contents were expressed in terms of $\mu$ moles of GSH/mg tissue. Oxidized GSH was quantitated by subtracting the value of GSH reduced from TG.

\section{Reduced GSH}

Reduced GSH is a non-protein sulfhydryl compound estimated by the method of Ellman in which DTNB, a disulfide compound is readily reduced by sulfhydryl compounds to release nitromercaptobenzoic acid anion that yields an intense yellow color to be read at $412 \mathrm{~nm}$ [19]. Briefly, $0.1 \mathrm{ml}$ of TCA (25\%) was added to tissue homogenate (500 $\mu \mathrm{l}$ ) and centrifuged at $2000 \mathrm{~g}$ for $15 \mathrm{~min}$. The supernatant obtained was further diluted with $0.2 \mathrm{M}$ PBS $(\mathrm{pH}$ 8.0) and mixed with freshly prepared $10 \mathrm{mM}$ DTNB made in $0.2 \mathrm{M}$ phosphate buffer ( $\mathrm{pH}$ 8.0). The optical density of the yellow colored complex formed by the reaction of GSH and DTNB (Ellman's reaction) was measured on a double beam 
spectrophotometer at $412 \mathrm{~nm}$ against a reference that contained 25\% TCA instead of the sample.

Molar absorption coefficient of GSH 13.6/M/cm.

\section{Glutathione-S-transferase (GST)}

GST activity was determined using the method of Habig et al. [20]. GST catalyzes the formation of GSH conjugates of 1-chloro-2,4dinitrobenzene,1,2-dichloro-4-nitrobenzene (CDNB), which absorb maximum at $340 \mathrm{~nm}$ and has an extinction coefficient of $9.6 / \mathrm{mM} / \mathrm{cm}$. The assay involved the use of CDNB as a substrate for GST. The tissue homogenate was added to the reaction mixture consisting of sodium phosphate buffer (100 mM and $\mathrm{pH}$ 6.5), CDNB and GSH and the absorbance was recorded at $340 \mathrm{~nm}$ for $3 \mathrm{~min}$. The activity was expressed as $\mu \mathrm{mol}$ CDNB conjugate $/ \mathrm{min} / \mathrm{mg}$ protein using an extinction coefficient of $9.6 / \mathrm{mM} / \mathrm{cm}$.

\section{Protein estimation}

Protein contents were estimated using the method of Lowry et al. [21].

\section{Statistical analysis}

The statistical significance of the data was determined using one-way analysis of variance (ANOVA) and a multiple post-hoc tests (Student Newman-Keuls). The results were represented as mean \pm S.D of six observations. The comparisons were made as follows:

${ }^{*} \mathrm{p} \leq 0.05,{ }^{* *} \mathrm{p} \leq 0.01$, and ${ }^{* * *} \mathrm{p} \leq 0.001$ by Newman-Keuls test when the values are compared to the sham control group.

$\# \mathrm{p} \leq 0.05,{ }^{\#} \mathrm{p} \leq 0.01$, and $\mathrm{d}^{\# \# \#} \mathrm{p} \leq 0.001$ by Newman-Keuls test when the values are compared to Group II.

\section{RESULTS}

LPO

Intracerebroventricular administration of $A \beta$ caused a statistically significant increase in the levels of LPO as compared to the sham control animals (Table 1). Fractionated X-irradiation brought a decrease in the MDA levels indicative of its normalization whereas no significant change in LPO levels was observed in the radiation control rats as compared to the sham control.

\section{SOD and catalase}

An increase in the activity of CAT was observed in the cerebral cortex of the amyloid injected rats as compared to the sham control group. However, X-irradiation to the amyloid treated rats was able to significantly reduce the elevated catalase levels. On the contrary, SOD levels significantly decreased in the amyloid injected rats that restored its level in the group that was subsequently treated with X-rays (Table 2).

\section{GSH system}

The reduced GSH levels, the GST activity, and the GR levels were significantly decreased in the cortex of the amyloid injected rats when

Table 1: Effect of fractionated low dose X-irradiation on LPO levels in the cerebral cortex of rat brain subjected to $A \beta$ treatment

\begin{tabular}{ll}
\hline Group & $\begin{array}{l}\text { LPO } \\
\text { (nanomoles of MDA formed/min/mg protein) }\end{array}$ \\
\hline Sham control & $0.0345 \pm 0.0066$ \\
$\mathrm{~A} \beta$ & $0.064 \pm 0.02^{* *}$ \\
Radiation control & $0.043 \pm 0.013$ \\
$\mathrm{~A} \beta$ +radiation & $0.0458 \pm 0.0106^{\#}$ \\
\hline
\end{tabular}

${ }^{*} \mathrm{p} \leq 0.05,{ }^{* *} \mathrm{p} \leq 0.01$, and ${ }^{* * *} \mathrm{p} \leq 0.001$ by Newman-Keuls test when the values are compared to Sham control group. ${ }^{\#} \mathrm{p} \leq 0.05,{ }^{\# \#} \mathrm{p} \leq 0.01$, and ${ }^{\# \# \#} \mathrm{p} \leq 0.001$

by Newman-Keuls test when the values are compared to $A \beta$ group.

A $\beta$ : Amyloid-beta, MDA: Malondialdehyde, LPO: Lipid peroxidation compared with the control group. However, the TG content was found to increase in the amyloid treated group whereas with $\mathrm{X}$-irradiation the levels attenuated significantly (Tables 3 and 4).

\section{DISCUSSION}

A number of molecular and cellular events have been implicated in the initiation and development of an $\mathrm{AD}$, oxidative stress to playing a crucial role in its pathogenesis [22,23]. Brain is more vulnerable to oxidative damage than all other organs due to high levels of polyunsaturated fatty acids and high oxygen utilization [23]. High levels of $A \beta$ induce oxidative stress impairing cellular ion homeostasis that renders excitotoxicity to neurons eventually leading to apoptosis [24]. In our experimental study, we observed amplified LPO levels with the administration of A $\beta$. LPO is a self propogative process of oxidative degradation of polyunsaturated fatty acids in biological membranes leading to disruption of their structure and functions. Intracerebroventricular administration of $A \beta$ led to a significant elevation of MDA as compared to control animals possibly due to the interaction of reactive oxygen species with the membrane lipids, membrane-bound proteins and eventually affecting the activity of ion channels too. A significant elevation in the levels of 4-hydroxynonal has been reported in the cortex, amygdala, and hippocampal regions of the AD brains [25]. A $\beta$ has also been shown to stimulate ROS production and LPO in primary cortical neurons [26,27]. However, the levels of MDA decreased post low dose fractionated $\mathrm{X}$-irradiation suggesting its neuroprotective role. The decrease may be attributed to free radicals scavenging in the cells that further inhibit peroxidation of the labile unsaturated fatty acids leading to membrane stabilization [28].

GSH is a ubiquitous tripeptide, which due to its thiol group in the cysteine residue plays a crucial role in detoxification of reactive oxygen species and peroxides either by directly interacting with reactive oxygen/nitrogen species or indirectly by working as a cofactor for various enzymes [28-31]. Thus, depletion in the levels of GSH under oxidative stress induced by $A \beta$ administration suggests consumption of GSH to neutralize free radicals produced by increased LPO [32].

The oxidized and reduced forms of GSH (GSSG and GSH) act together to maintain the redox status of the cell [30]. GR uses NADPH as the electron source to convert GSSG to GSH, which gets oxidized back to GSSG by the action of GST. As a consequence of GSH depletion post A $\beta$ treatment, a decline in GST activity was also observed as GSH serves as a substrate for GST and the lack of substrate brought down the levels of GST too. However, a significant rise in the enzymatic activity of GST and intracellular stores of GSH post-X-irradiation suggests a decrease in the oxidative injury of the brain cells. Moreover, a decrease in the GR levels of the brain induced by amyloid also justifies the decrease in GSH content of the cell and further confirms our findings. Further, under oxidative stress conditions, with depletion in the GSH levels, a concomitant increase in the GSSG (oxidized GSH) level occurs disbalancing the GSH: GSSG ratio thereby increasing the TG levels of the oxidatively stressed brain cells in AD condition [33].

Specific antioxidant enzyme activity of SOD was found to decrease significantly post-intracerebroventricular administration of amyloid. The metalloenzyme, SOD is the primary scavenger of superoxide anion [34,35], the synthesis of which is stimulated by the production of ROS [36]. SOD inhibits $\mathrm{OH}^{-}$production by scavenging $\mathrm{O}^{2-}$ thus converting the superoxide anion to oxygen and hydrogen peroxide [37] and hence it can be postulated that the decrease in enzyme activity is presumably in advanced stages of peroxidation where the enzyme becomes depleted and thus unable to scavenge the free radicals in the cells [38]. The X-irradiation post- $\mathrm{A} \beta$ administration tends to normalize the SOD levels indicative of triggering the body's antioxidant defense system. However, the increase in catalase activity that reduced to near control levels after fractionated radiation treatment suggests the increase in enzyme activity to combat the adverse effects of the increased free radicals due to the amyloid-induced neurotoxicity. The 
Table 2: Effect of fractionated low dose X-irradiation on catalase and SOD levels in the cerebral cortex of rat brain subjected to A $\beta$ treatment

\begin{tabular}{lll}
\hline Group & Catalase $\left(\boldsymbol{\mu m o l e s}\right.$ of $\mathbf{H}_{2} \mathbf{O}_{2}$ decomposed $/ \mathbf{m i n} / \mathbf{m g}$ protein) & SOD (units/min/mg protein) \\
\hline Sham control & $16.73 \pm 4.22$ & $6.21 \pm 1.08$ \\
$\mathrm{~A} \beta$ & $22.05 \pm 5.54^{* *}$ & $4.95 \pm 1.24^{* *}$ \\
Radiation control & $18.77 \pm 4.64$ & $5.83 \pm 0.922^{\# \#}$ \\
A $\beta+$ radiation & $20.26 \pm 4.08^{*}$ & $5.25 \pm 2.15^{\# \#, *}$ \\
\hline
\end{tabular}

${ }^{*} \mathrm{p} \leq 0.05,{ }^{* *} \mathrm{p} \leq 0.01$, and ${ }^{* * *} \mathrm{p} \leq 0.001$ by Newman-Keuls test when the values are compared to sham control group. ${ }^{\#} \mathrm{p} \leq 0.05$, ${ }^{\# \#} \mathrm{p} \leq 0.01$, and ${ }^{\# \# \#} \mathrm{p} \leq 0.001$ by Newman-Keuls test when the values are compared to $A \beta$ group. $A \beta$ : Amyloid-beta, SOD: Superoxide dismutase

Table 3: Effect of fractionated low dose X-irradiation on glutathione system in the cerebral cortex of rat brain subjected to $A \beta$ treatment

\begin{tabular}{llll}
\hline Group & GSH $(\boldsymbol{\mu m o l e s} / \mathbf{m g}$ protein) & GSSG $(\boldsymbol{\mu m o l e s} / \mathbf{m g}$ protein) & TG $(\boldsymbol{\mu m o l e s} / \mathbf{m g}$ protein) \\
\hline Sham control & $0.1362 \pm 0.05$ & $0.238 \pm 0.147$ & $0.374 \pm 0.16$ \\
A $\beta$ & $0.0535 \pm 0.0084^{* * *}$ & $0.309 \pm 0.01^{* *}$ & $0.407 \pm 0.011^{* * *}$ \\
Radiation control & $0.108 \pm 0.10^{\# \#}$ & $0.252 \pm 0.055^{\# \#}$ & $0.329 \pm 0.054^{\# \#}$ \\
A $\beta+$ radiation & $0.093 \pm 0.01^{*, \#}$ & $0.211 \pm 0.018^{* *, \#}$ & $0.296 \pm 0.022^{* *, \# \#}$ \\
\hline
\end{tabular}

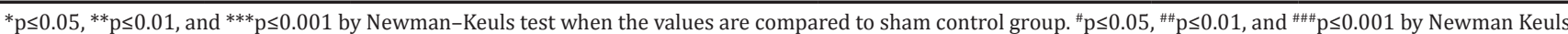
test when the values are compared to A $\beta$ group. A 3 : Amyloid-beta, GSH: Glutathione, GSSG: Glutathione disulfide, TG: Total glutathione

Table 4: Effect of fractionated low dose X-irradiation on Glutathione system in the cerebral cortex of rat brain subjected to $A \beta$ treatment

\begin{tabular}{lll}
\hline Group & GR (nanomoles/min/mg protein) & GST ( $\boldsymbol{\mu m o l ~ c o n j u g a t e ~ f o r m e d / m i n / m g ~ p r o t e i n ) ~}$ \\
\hline Sham control & $22.28 \pm 2.91$ & $1.67 \pm 0.65$ \\
$\mathrm{~A} \beta$ & $15.20 \pm 1.47^{* *}$ & $1.10 \pm 0.08^{* * *}$ \\
Radiation control & $23.44 \pm 4.73$ & $1.54 \pm 0.04$ \\
A $\beta+$ radiation & $19.24 \pm 4.29^{\#}$ & $1.49 \pm 0.18^{*, \# \#}$ \\
\hline
\end{tabular}

${ }^{*} \mathrm{p} \leq 0.05,{ }^{* *} \mathrm{p} \leq 0.01$, and ${ }^{* * *} \mathrm{p} \leq 0.001$ by Newman-Keuls test when the values are compared to sham control group. ${ }^{\#} \mathrm{p} \leq 0.05$, ${ }^{\# \#} \mathrm{p} \leq 0.01$, and ${ }^{\# \# \#} \mathrm{p} \leq 0.001$ by Newman-Keuls test when the values are compared to $A \beta$ group. $A \beta$ : Amyloid-beta, GR: Glutathione reductase

possible explanation for the elevated activity of catalase and depressed activity of SOD can presumably be due to alteration of the activity of transcription factor nuclear factor E2-related factor 2 by ionizing radiations which further has an impact on the action of antioxidant proteins (such as SOD and glutathione peroxidase) and free radical scavenging enzymes $[39,40]$.

\section{CONCLUSION}

The present study evaluated the therapeutic potential of low dose fractionated cranial $X$-irradiation by mitigating the $A \beta$-induced oxidative stress suggesting a novel treatment for AD-associated pathologies.

\section{AUTHORS' CONTRIBUTION}

All the persons who have participated in the study have been listed as authors. Conception and design of the study: Anna A Khan, Devinder K Dhawan, and Vijayta D Chadha. Experimental data collection: Anna A Khan and Rozy Kamal. Drafting and revision of manuscript: Anna A Khan, Rozy Kamal, Devinder K Dhawan, and Vijayta D Chadha.

\section{CONFLICTS OF INTEREST}

Authors declare that there are no conflicts of interest.

\section{REFERENCES}

1. Brookmeyer R, Gray S, Kawas C. Projections of Alzheimer's disease in the United States and the public health impact of delaying disease onset. Am J Public Health 1998;88:1337-42.

2. McKhann G, Drachman D, Folstein M, Katzman R, Price D, Stadlan EM, et al. Clinical diagnosis of Alzheimer's disease: Report of the NINCDS-ADRDA work group under the auspices of department of health and human services task force on Alzheimer's disease. Neurology 1984;34:939-44.

3. Alzheimer's Disease International World Alzheimer Report. Dementia and Risk Reduction: An Analysis of Protective and Modifiable Factors; 2014.

4. Alzheimer A. Über eine eigenartige erkankung der hirnrinde. Allg zeitschr psychiatr. Psychiatr-Gerichtl Med 1907;109:146-8.

5. Cleary J, Hittner JM, Semotuk M, Mantyh P, O'Hare E. Betaamyloid(1-40) effects on behavior and memory. Brain Res 1995;682:69-74.

6. Evin G, Weidemann A. Biogenesis and metabolism of Alzheimer's disease abeta amyloid peptides. Peptides 2002;23:1285-97.

7. Harper JD, Lansbury PT Jr. Models of amyloid seeding in Alzheimer's disease and scrapie: Mechanistic truths and physiological consequences of the time-dependent solubility of amyloid proteins. Annu Rev Biochem 1997;66:385-407.

8. Blennow K, Hampel H. CSF markers for incipient Alzheimer's disease. Lancet Neurol 2003;2:605-13.

9. Mandelkow EM, Mandelkow E. Tau in Alzheimer's disease. Trends Cell Biol 1998;8:425-7.

10. Minati L, Edginton T, Bruzzone MG, Giaccone G. Current concepts in Alzheimer's disease: A multidisciplinary review. Am J Alzheimers Dis Other Demen 2009;24:95-121.

11. Singh A, Jatav VK, Sharma S. Virtual screening and admet analysis for identification of inhibitors against acetylcholinesterase associated with Alzheimer's disease. Int J Pharm Pharm Sci 2014;6:155-9.

12. Wilson GD, Marples B. A new use for an old treatment: Radiation therapy and Alzheimer's disease. Radiat Res 2016;185:443-8.

13. Fang F, Yan N, Feng Z, Liu X, Xiao Z, Wen M, et al. Alzheimer's disease animal model by aluminum, beta-amyloid and transforming growth factor beta-1. Aging Neurodegener 2013;1:15-9

14. Wills ED. Mechanisms of lipid peroxide formation in animal tissues. Biochem J 1966;99:667-76.

15. Kono Y. Generation of superoxide radical during autoxidation of hydroxylamine and an assay for superoxide dismutase. Arch Biochem Biophys 1978; 186:189-95.

16. Catalase LH. In: Bergmeyer HU, editor. Methods of Enzymatic Analysis. New York: Academic Press; 1971. P. 885-93.

17. Carlberg I, Mannervik B. Glutathione reductase. Methods Enzymol 1985;113:484-90.

18. Zahler WL, Cleland WW. A specific and sensitive assay for disulfides. J Biol Chem 1968;243:716-9.

19. Ellman GL. Tissue sulfhydryl groups. Arch Biochem Biophys 1959;82:70-7.

20. Habig WH, Pabst MJ, Jakoby WB. Glutathione S-transferases. The first enzymatic step in mercapturic acid formation. J Biol Chem 
1974;249:7130-9.

21. Lowry OH, Rosebrough NJ, Farr AL, Randall RJ. Protein measurement with the folin phenol reagent. J Biol Chem 1951;193:265-75.

22. Lecanu L, Greeson J, Papadopoulos V. Beta-amyloid and oxidative stress jointly induce neuronal death, amyloid deposits, gliosis, and memory impairment in the rat brain. Pharmacology 2006;76:19-33.

23. Butterfield DA, Reed T, Newman SF, Sultana R. Roles of amyloid betapeptide-associated oxidative stress and brain protein modifications in the pathogenesis of Alzheimer's disease and mild cognitive impairment. Free Radic Biol Med 2007;43:658-77.

24. Mattson MP, Chan SL. Dysregulation of cellular calcium homeostasis in Alzheimer's disease: Bad genes and bad habits. J Mol Neurosci 2001;17:205-24.

25. Kaur K, Kaur R, Kaur M. Recent advances in Alzheimer's disease: Causes and treatment. Int J Pharm Pharm Sci 2016;8:8-15.

26. Sponne I, Fifre A, Drouet B, Klein C, Koziel V, Pinçon-Raymond M, et al. Apoptotic neuronal cell death induced by the non-fibrillar amyloidbeta peptide proceeds through an early reactive oxygen speciesdependent cytoskeleton perturbation. J Biol Chem 2003;278:3437-45.

27. Florent S, Malaplate-Armand C, Youssef I, Kriem B, Koziel V, Escanyé MC, et al. Docosahexaenoic acid prevents neuronal apoptosis induced by soluble amyloid-beta oligomers. J Neurochem 2006;96:385-95.

28. Yu BP. Cellular defenses against damage from reactive oxygen species. Physiol Rev 1994;74:139-62.

29. Saharan S, Mandal PK. The emerging role of glutathione in Alzheimer's disease. J Alzheimers Dis 2014;40:519-29.

30. Lushchak VI. Glutathione homeostasis and functions: Potential targets for medical interventions. J Amino Acids 2012;2012:736837.

31. Zitka O, Skalickova S, Gumulec J, Masarik M, Adam V, Hubalek J, et al. Redox status expressed as GSH: GSSG ratio as a marker for oxidative stress in paediatric tumour patients. Oncol Lett 2012;4:1247-53.

32. Murakami K, Yoshino M. Aluminum decreases the glutathione regeneration by the inhibition of NADP-isocitrate dehydrogenase in mitochondria. J Cell Biochem 2004;93:1267-71.

33. Sharma N, Kapoor M, Nehru B. Spinacea oleracea extract protects against LPS induced oxidative stress, inflammatory response and ensuing biochemical, neurochemical and neurobehavioral impairment in mice. Int J Pharm Pharm Sci 2014;6:203-10.

34. Wetscher GJ, Hinder PR, Bagchi D, Perdikis G, Redmond EJ, Glaser K, et al. Free radical scavengers prevent reflux esophagitis in rats. Dig Dis Sci 1995;40:1292-6.

35. Jiménez P, Piazuelo E, Sánchez MT, Ortego J, Soteras F, Lanas A, et al. Free radicals and antioxidant systems in reflux esophagitis and barrett's esophagus. World J Gastroenterol 2005;11:2697-703.

36. Jyoti A, Sethi P, Sharma D. Bacopa monniera prevents from aluminium neurotoxicity in the cerebral cortex of rat brain. J Ehtnophram 2007;111:56-62.

37. Fridovich I. Superoxide radical and superoxide dismutases. Ann Rev Biochem 1994;64:97-112.

38. Murakami K, Murata N, Noda Y, Tahara S, Kaneko T, Kinoshita N, et al. SOD1 (copper/zinc superoxide dismutase) deficiency drives amyloid $\beta$ protein oligomerization and memory loss in mouse model of alzheimer disease. J Biol Chem 2011;286:44557-68.

39. Large M, Hehlgans S, Reichert S, Gaipl US, Fournier C, Rödel C, et al. Study of the anti-inflammatory effects of low-dose radiation: The contribution of biphasic regulation of the antioxidative system in endothelial cells. Strahlenther Onkol 2015;191:742-9.

40. Kaur A, Singla N, Dhawan DK. Low dose X-irradiation mitigates diazepam induced depression in rat brain. Regul Toxicol Pharmacol 2016;80:82-90. 